Reprod. Nutr. Dévelop., 1980, 20 (1 B), 331-337.

\title{
Maturation of glucocorticosteroid activity in the foetal guinea-pig during the end of gestation
}

\author{
par M. DALLE, P. DELOST
}

Laboratoire de Physiologie Animale et E.R.A. C.N.R.S.

Endocrinologie du Développement

Universifé de Clermont-Ferrand, Ensemble Scientifique des Cézeaux

B. P. 45, 63170 Aubière.

Summary. Cortisol levels were very high in maternal and foetal plasma during the last days of pregnancy. The percentage of free cortisol was maximal in plasmas of the mother and the foetus on the last day before parturition ; the increase in free cortisol levels resulted from the saturation of transcortin binding capacity and from a higher adrenal secretion rate at that time due to stress at the onset of labor. On the last day of pregnancy the foetal adrenals could cover the hormonal needs of the foetus, the foetal-maternal transter of cortisol being similar to the maternal-foetal transfer. However, the low TCM of cortisol indicated that cortisol catabolism was still immature. The origin of foetal transcortin is still unknown.

\section{Introduction.}

In numerous mammalian species, parturition is associated with an increase in foetal, and sometimes maternal, corticosteroid plasma levels (Bassett and Thornburn, 1969 ; Kamoun, 1970 ; Mulay et al., 1973 ; Illingworth et al., 1974 ; Jones, 1974 ; Dalle et al., 1978). Such an increase results from changes in foetal and maternal adrenal activity and in hormonal transfers across the placenta. High plasma cortisol levels have been observed in newborn guinea-pigs (Dalle and Delost, 1974). These high levels result from a regular rise in foetal plasma cortisol levels during the last days of gestation, which parallels the increase in maternal plasma and adrenal cortisol concentrations, foetal adrenal cortisol content increasing only during the last 24 hrs of gestation (Dalle and Delost, 1976). Recent studies (Dalle and Delost, 1979) have shown that 90 p. 100 of the cortisol found in the foetal plasma during the end of gestation is of maternal origin. These studies have also demonstrated that placental transfers of corfisol both from the mother to the foelus and from the foetus to the mother increase near parturition, as does the cortisol secretion rate of the foetal adrenals at that time. Thus, the foetal secretion rate of cortisol becomes similar to its production rate in the newborn. In the work reported here, we have measured levels of free cortisol and the different parameters of cortisol binding in the plasmas of dams, foetuses and newborns. 


\section{Material and methods.}

Female guinea-pigs (Dunkin-Hartley strain ; length of gestation : 68 days) were caged with a male during $24 \mathrm{hrs}$ at oestrus time when the vagina was entirely open. Thus, mating time was known at \pm 12 hrs. The pregnant mothers and their foetuses, obtained by Caesarean section, were killed by decapitation at $60,62,64,66$ and 68 days of gestation between 9 and $11 \mathrm{a} . \mathrm{m}$. The newborns and their mothers were killed exactly at $0 \mathrm{hr}$ and $50 \mathrm{hrs}$ post-partum. Each group included 6-10 animals.

Plasma cortisol levels were estimated by competitive protein binding according to Murphy (1967), modified as described previously (Dalle and Delost, 1976). Cortisol binding parameters were determined using the method of Pearlman and Crepy (1967), adapted for corticosteroids (Pradier, 1979). Non specific binding of plasma cortisol (other than albumin-bound) was undetectable, and transcortin-binding capacity was similar to that measured with the other usual methods used in our laboratory. The ratio of plasma cortisol : progesterone was high (around 30) (Dalle and Delost, 1976), and progesterone did not interact in the binding of cortisol. The parameters were calculated according to Labrie et al. (1966). The binding capacity of transcortin for cortisol was expressed as $\mu \mathrm{g}$ of cortisol/100 $\mathrm{ml}$ plasma. The results were expressed as mean \pm SEM ; the statistical significance was evaluafed using Student's $t$ test.

\section{Results.}

Pattern of transcortin binding capacity for cortisol (fig. 1). - During the last week of pregnancy the binding capacity of transcortin for cortisol in pregnant guinea-pigs was 5 times higher than in non-pregnant females. It decreased sharply just before $(-38 \mathrm{p}$. 100 between day 68 and parturition ; $P<0.05)$ and after parturition until day 20 post-

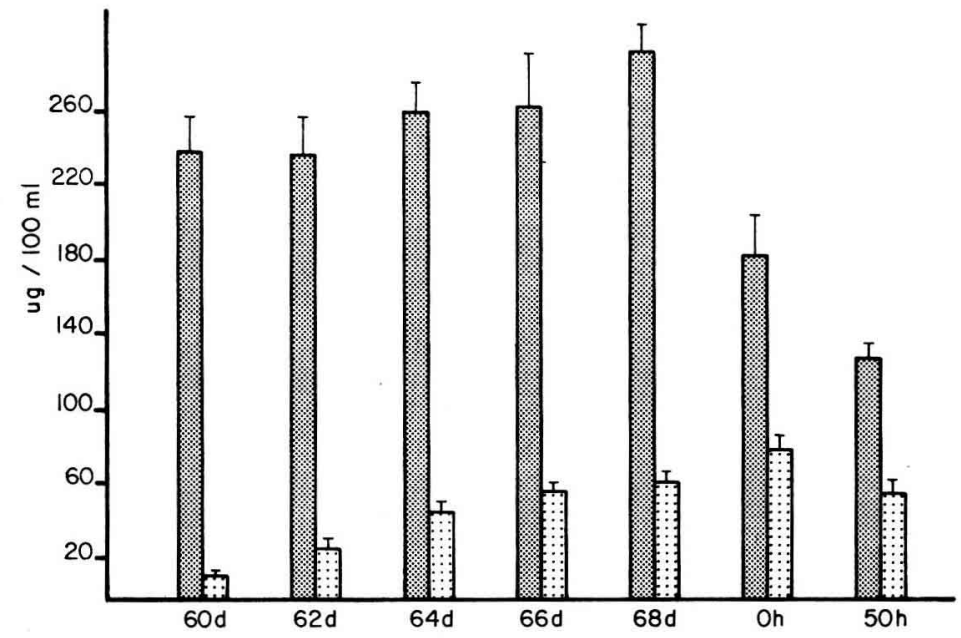

FG. 1. - Changes in transcortin binding capocity for cortisol in maternal ( and foetal and neonatal ( $\square ; n=6$ ) guinea-pigs during the perinalal period. 
partum when the values were similar to those measured in adult females (about $50 \mu \mathrm{g} / 100 \mathrm{ml}$ ). In foetuses the binding capacity of transcortin for cortisol was low on day 60 of gestation $(15 \mu \mathrm{g} / 100 \mathrm{ml})$. Thus, it increased during the last week, being maximal at birth $(80 \mu \mathrm{g} / 100 \mathrm{ml})$. However, it always remained under the maternal values.

Pattern of $S_{\mathrm{A}} K_{\mathrm{A}}$ (albumin binding factor for cortisol). The part of cortisol bound to albumin equalled free cortisol $\times \mathrm{S}_{\mathrm{A}} \mathrm{K}_{\mathrm{A}}\left(\mathrm{S}_{\mathrm{A}}\right.$ : albumin binding capacity for cortisol ; $K_{A}$ : albumin-cortisol binding constant).

In dams $S_{A} K_{A}$ values were similar to those measured in non-pregnant females (1.5-3.0). These values did not vary significantly during the end of gestation. Foetal $S_{A} K_{A}$ values ranged between 0.4 and 0.7 , increasing at birth $(+245$ p. 100, $P<0.05)$. $S_{A} K_{A}$ values were then not significantly different in newborns, adult females and pregnant animals.

$\mathrm{K}_{T}$ values (transcortin binding constant for cortisol). During the whole experimental period, $K_{T}$ values were similar in mothers $\left(1.5 \pm 0.210^{8} \mathrm{M}^{-1}\right)$, foetuses $\left(1.3 \pm 0.210^{8} \mathrm{M}^{-1}\right)$ and adult females $\left(1.0 \pm 0.310^{8} \mathrm{M}^{-1}\right)$.

Free and bound cortisol plasma levels in mothers (fig. 2 and fig. 3). - During the last week of pregnancy plasma cortisol levels were very high; they increased until day 68 and then regularly decreased (- 45 p. 100 between day 68 and parturition; $\mathrm{P}<0.001 ;-53$ p. 100 between parturition and $50 \mathrm{hrs}$ post-partum ; $\mathrm{P}<0.001)$ until day 20 post-partum when they were similar to those measured in the non-pregnant females $(50 \mu \mathrm{g} / 100 \mathrm{ml})$. A high percentage $(96 \mathrm{p} .100)$ of cortisol bound to transcortin was found at day 60 of gestation. This percentage decreased to 63 p. 100 on day 68 then rose to 93 p. 100 during the 50 hrs post-partum. This last value was similar to the one measured in non-pregnant females. Plasma cortisol bound to albumin increased from 2 p. 100 on day 60 to 28 p. 100 on day 66 . It remained high on day 68 (23 p. 100)

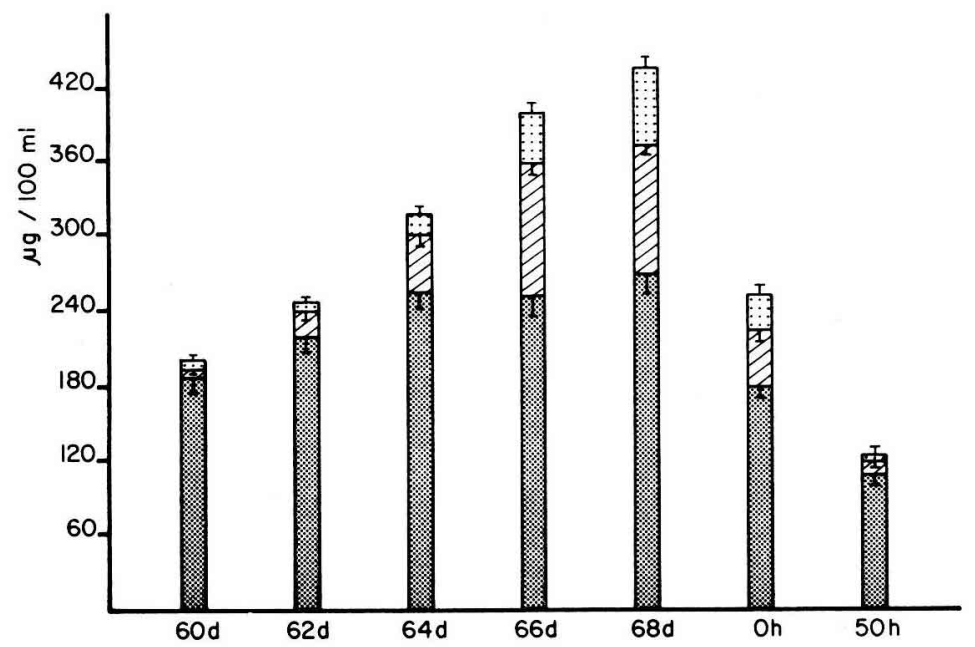

FIG. 2. - Development of free ( $\square$ ), albumin-bound ( $E Z A)$ 
and at parturition (18 p. 100). However at $50 \mathrm{hrs}$ post-partum the percentage of plasma cortisol bound to albumin (6 p. 100) was similar to the level measured in non-pregnant females. Plasma free cortisol paralleled albumin-bound cortisol. It increased from 2 p. 100 on day 60 to 14 p. 100 on day 68 (highest value; $61 \mu \mathrm{g} / 100 \mathrm{ml}$ ), and plasma free cortisol levels were similar to those of the adult at $50 \mathrm{hrs}$ post-partum.

Free and bound cortisol levels in the foetus (fig. 3 and fig. 4). - The percentage of transcortin-bound cortisol ( 80 p. 100 of plasma cortisol between days 60 and 64)

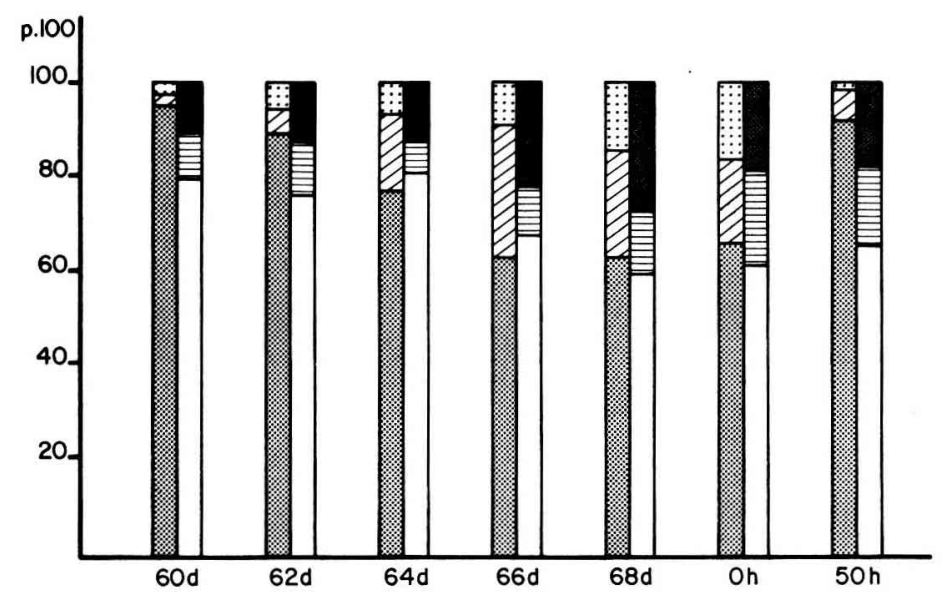

FIG. 3. - Changes in percentage of free, albumin-bound, and transcortin-bound cortisol in mother, foetal and newborn guineo-pigs during the perinalal period. Mother : free ( $\square)$; albuminbound (EZZ); transcortin-bound (1). Foetal and newborn: free ( bound (

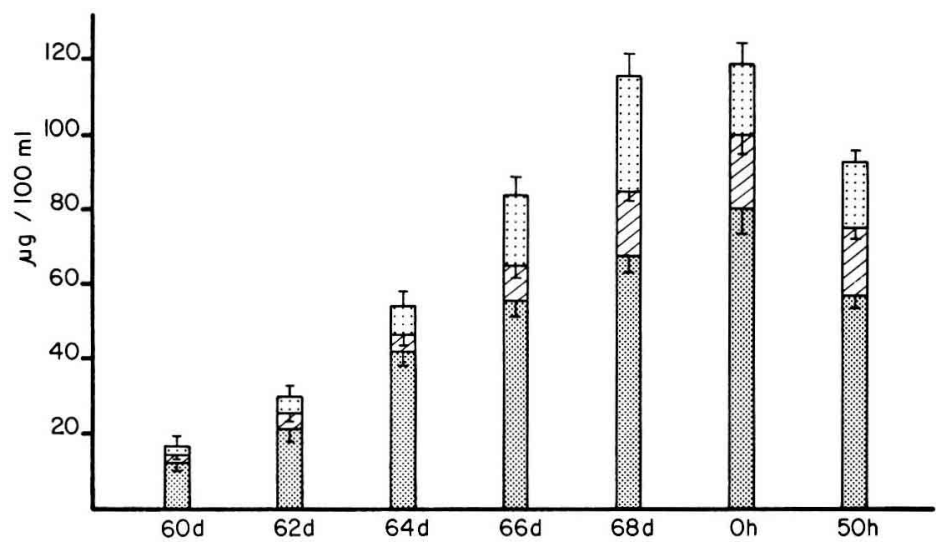

FiG. 4. - Development of free cortisol (

). albumin-bound corfisol (DZZ) and transcortin-bound cortisol ( $)$ in foetal and newborn guinea-pigs around parturition. 
decreased until birth (57 p. 100). During the whole experimental period the percentage of albumin-bound cortisol remained around 10 p. 100, although free cortisol rose sharply from 13 p. 100 on day 60 to 27 p. 100 on day 68 . At those stages free cortisol levels were $7 \mu \mathrm{g} / 100 \mathrm{ml}$ on day $64,19 \mu \mathrm{g} / 100 \mathrm{ml}$ on day $66(+171 \mathrm{p} .100$, $\mathrm{P}<0.01$ ) and $33 \mu \mathrm{g} / 100 \mathrm{ml}$ on day 68 ( $+74 \mathrm{p} .100$ between days 66 and $68, \mathrm{p}<0.05)$.

\section{Discussion.}

The estimation of plasma and adrenal cortisol concentrations (associated with the measurement of metabolism) and the transfer and the binding of plasma cortisol in maternal and foetal guinea-pigs in the last days of gestation and at birth could provide a better understanding of the maturation of foetal adrenal activity under maternal influence. High plasma cortisol levels and high transcortin binding capacity were found in pregnant guinea-pigs (Gala and Westphal, 1967 ; Diamond et al., 1969). These values were maximal on day 68 , and decreased sharply at parturition as did progesterone and PBG plasma levels (Lea ef al., 1976). High plasma PBG levels were associated with very low progesterone TCM during gestation (Illingworth et al., 1970). Similarly, high transcortin plasma levels paralleled a low cortisol TCM (3 times lower than in non-pregnant females) (Dalle and Delost, 1979).

During the last week of gestation plasma cortisol levels increased significantly $(+125$ p. $100, P<0.001)$. During the same period plasma transcortin levels did not vary significantly but free cortisol levels increased from 7 to $61 \mu \mathrm{g} / 100 \mathrm{ml}(+770 \mathrm{p} .100$, $P<0.001)$; simultaneously, cortisol transfer across the placenta from the mother to the foetus increased $(+130$ p. $100, P<0.01)$. However these results do not indicate whether the two processes were correlated. Indeed, numerous morphological changes occurred in the guinea-pig placenta during the end of pregnancy which might explain the increase in cortisol transfers (Firth and Farr, 1977 ; Kaufmann and Davidoff, 1977).

In foetal guinea-pigs the increase in plasma cortisol levels paralleled that of transcortin during the end of gestation; similar results have been demonstrated in foetal sheep (Fairclough and Liggins, 1975) and rat (Martin et al., 1977 ; Van Baelen et al., 1977). As in rat foetuses (Van Baelen ef al., 1977), free cortisol levels in foetal guineapigs increased sharply during the last days of gestation. The transfer of corticosteroids across the placenta has never been studied in rats. In guinea-pigs the rise in free cortisol levels occurring just before parturition, in foetuses as in dams, seemed to be due to an increased cortisol secretion rate of the foetal and maternal adrenals. This increased rate might result from a response of the adrenals to the stress associated with the onset of labor. At that time, the transfer of cortisol across the placenta from the foetus to the mother equals that from the mother to the foetus (Dalle and Delost, 1979).

In conclusion, during the end of gestation in guinea-pig the simultaneous measurement of plasma and adrenal cortisol levels, binding, and cortisol metabolism and transfer in both dams and foetuses, demonstrates that, although a large part of foetal cortisol is of maternal origin, the foetal adrenals are able to cover the hormonal needs of the foetus just before term. At that time, the enzymatic systems involved in cortisol catabolism are still immature.

In spite of high foetal levels, the origin of transcortin remains unknown. It may be of foetal origin, as in birds (Gasc and Martin, 1978), its production being regulated by 
hormones such as thyroxine and cortisol, or it may be of maternal origin, as in the mouse (Savu et al., 1977). The hypothesis of a placental transfer of this protein in the guinea-pig will be investigated in our laboratory. The increase in free cortisol levels observed in both dams and foetuses during the last two days of pregnancy results from adrenal response to the onset of labor. The rise in foetal free cortisol levels argues in favour of foetal adrenal maturity occurring just before birth.

5e Réunion du groupe Développement I.N.R.A., Clermont-Ferrand/Theix, 17-18 mai 1979.

Résumé. Les cortisolémies fœtale et maternelle augmentent régulièrement et fortement au cours de la dernière semaine de la gestation chez le cobaye. Le pourcentage de cortisol libre est maximum chez la mère et le fotus la veille de la parturition ; son augmentation provient d'une part de la saturation de la capacité de liaison de la transcortine pourtant très élevée à ce moment et d'autre part d'une sécrétion surrénalienne maternelle et fotale en cortisol stimulée par le stress de la parturition. Chez le fœtus en effet, les surrénales ont atteint, juste avant la naissance, un degré de maturation suffisant pour assurer les besoins de l'organisme du nouveau-né en hormone et le fœtus retransfère à la mère la totalité du cortisol que celle-ci lui envoie. Toutefois, le catabolisme hépatique du cortisol reste faible au cours de cette période et le problème de l'origine de la transcortine du foetus reste posé.

\section{References}

BASSETT J. M., THORNBURN G. D., 1969. Foetal plasma corticosteroids and the initiation of parturition in sheep. J. Endocr., 44, 285-286.

DALLE M., DELOST P., 1974. Changes in the concentrations of cortisol and corticosterone in the plasma and adrenal glands of the guinea-pig from birth to weaning. J. Endocr., 63, 483-488.

DALLE M., DELOST P., 1976. Plasma and adrenal cortisol concentrations in foetal, newborn and mother guinea-pigs during the perinatal period. J. Endocr., 70, 207-214.

DALLE M., GIRY J., GAY M., DELOST P. 1978. Perinatal changes in plasma and adrenal corticosterone and aldosterone concentrations in the mouse. J. Endocr., 76, 303-309.

DALLE M., DELOST P., 1979. Foetal-maternal production and transfer of cortisol during the last days of gestation in the guinea-pig. J. Endocr., 82, 45-51.

DIAMOND M., RUST N., WESTPHAL U., 1969. High affinity binding of progesterone, testosterone and cortisol in normal and androgen-treated guinea-pigs during various reproduction stages. Relationship to masculinisation. Endocrinology, 84, 1143-1151.

FAIRCLOUGH R. J., LIGGINS G. C., 1975. Protein binding of plasma cortisol in the foetal lamb near term. J. Endocr., 67, 333-341.

FIRTH J. A., FARR A., 1977. Structural features and quantitative age-dependent changes in the intervascular barrier of the guinea-pig haemochorial placenta. Cell Tissue Res., 184, 507-517.

GALA R. R., WESTPHAL U., 1967. Corticosteroid-binding activity in serum of mouse, rabbit and guinea-pig during pregnancy and lactation : possible involvement in the initiation of lactation. Acta endocr., 55, 47-61.

GASC J. M., MARTIN B., 1978. Plasma corticosterone binding capacity in the partially decapitated chick embryo. Gen. comp. Endocr., 35, 274-279.

ILLINGWORTH D. V., HEAP R. B., PERRY J. S., 1970. Changes in the metabolic clearance rate of progesterone in the guinea-pig. J. Endocr., 48, 409-417.

ILLINGWORTH D. V., CHALLIS J. R. G., ACKLAND N., BURTON A. M., HEAP R. B., PERRY J. S., 1974. Parturition in the guinea-pig ; plasma levels of steroid hormones, steroid-binding proteins and oxytocin, and the effects of corticosteroids, prostaglandins and adrenocorticotrophin. J. Endocr., 63, 557-570.

JONES C. T., 1974. Corticosteroid concentrations in the plasma of fetal and maternal guinea-pigs during gestation. Endocrinology, 95, 1129-1133. 
KAMOUN A., 1970. Activité corticosurrénale au cours de la gestation, de la lactation et du développement pré- et post-natal chez le rat. J. Physiol., Paris, 62, 5-50.

KAUFMANN P., DAVIDOFF M., 1977. The guinea-pig placenta. Adv. Anat. Embryol. Cell Biol., 53, 1-90.

LABRIE F., LOISEL R., KOCH B., MARCEAU H., FORTIER C., 1966. Hormonal control of corticosteroid-binding by transcortin in the rat. Proc. Endoc. Soc., Chicago, 48, 64-68.

LEA O. A., BESSESEN A., STOA K. F., 1976. Progesterone-binding globulin and testosterone-binding activity in guinea-pig serum during pregnancy : relationship to progesterone and oestrogens Acta endocr., 81, 367-378.

MARTIN C. E., CAKE M. H., HARTMANN P. E., COOK I. F., 1977. Relationship between corticosteroids, maternal progesterone and parturition in the rat. Acta endocr., 84, 167-176.

MULAY S., GIANNOPOULOS G., SOLOMON S., 1973. Corticosteroid levels in the mother and foetus of the rabbit during gestation. Endocrinology, 93, 1342-1348.

MURPHY B. E. P., 1967. Some studies of the protein-binding of steroids and their application to the routine micro- and ultramicro-measurements of various steroids in body fluids by competitive protein-binding radioassay. J. clin. Endocrinol. Metab., 27, 973-990.

PEARLMAN W. H., CREPY O., 1967. Steroid protein interaction with particular reference to testosterone binding by human serum. J. biol. Chem., 242, 182-189.

PRADIER P., 1979. Liaison de la testostérone, de la dihydrotestostérone ef de l'aldostérone chez le foetus et le nouveau-né de cobaye pendant la période périnatale et chez la mère pendant la gestation. Th. $3^{\text {e }}$ cycle, Clermont-Ferrand, $138 \mathrm{pp}$.

SAVU L., NUNEZ E., JAYLE M. F., 1977. Corticosterone-binding by mouse sera during foetal and post-natal development. Acta endocr., 84, 177-190.

VAN BAELEN H., VANDOREN G., DE MOOR P., 1977. Concentration of transcortin in the pregnant rat and its foetus. J. Endocr., 75, 427-431. 